психотравмуючих обставин, тривогою та депресією, у фазі резистенції проявляється економією емоційної сфери та емоційно-моральною дезорієнтацією, у фазі виснаження - емоційним дефіцитом, психосоматичними і психовегетативними порушеннями. Встановлено, що у 2 викладачів з 27 сформувалися дві фази емоційного вигорання - напруження та резистенції, основними симптомами яких $є$ відчуття загнаності у клітку, що вказує на розвиток стану інтелектуально-емоційного затору та бажання швидшого завершення робочого дня, відчуття тривоги та депресії 3 паралельно сформованим симптомом редукції професійних обов'язків. Фаза резистенції була сформована у шести викладачів, домінуючими симптомами якої була редукція професійних обов'язків, що проявлялось зниженням інтересу до роботи та погіршенням професійної діяльності. Фази резистенції та виснаження сформувалася у чотирьох викладачів, найбільш вираженими симптомами яких були розширення сфери економії емоцій, що вказує на обмежене спілкування з аудиторією, зниження зацікавленості до роботи та емоційним дефіцитом, за якого люди втрачають професійні здібності із заміною позитивних емоцій негативними, стають грубими у спілкуванні. Виявлено, що у чотирьох викладачів переважно жіночої статі сформувалися всі три фази синдрому емоційного вигорання, для яких домінуючими були симптом переживання психотравмуючих обставин, що характеризується посиленням роздратування й недовіри до людей, накопиченням невдоволення ситуацією. Водночас найбільш вираженим є симптом розширення сфери економії емоцій, що вказує на небажання спілкування з аудиторією та зниження інтересу до роботи. Доведено, що у викладачів не виявлено особливостей проявів синдрому емоційного вигорання залежно від навчальної дисципліни, яку вони викладають, однак емоційне вигорання частіше розвивається при роботі зі студентами, у яких викладання предмету здійснюється англійською мовою.

Ключові слова: синдром емоційного вигорання, викладач, фаза напруження, фаза резистенції, фаза виснаження.

Reviewed by Doctor of Psychology, prof. A. Borysiuk

Submitted on 17, February, 2017

UDC: 159.9 .072 .5

DOI: https://doi.org/10.24195/2414-4665-2017-3-13

Maryna Puliaievska,

PhD (Candidate of Psychological Sciences), senior lecturer, Department of Humanities and Social Sciences, Interregional Academy of Personnel Management,

2, Frometivska Str., Kyiv, Ukraine

\title{
THE ROLE OF CONTEXT AND INTENT IN THE FORMATION OF PERCEPTUAL CONTENT AND BEHAVIOUR
}

The paper deals with the issues of interrelation between external objects perception, vectors of involvement and behaviours of individuals. Perceptual context is defined as a set of factors including conditions and content of individual's living and related "involvement vector", i.e. emotional and evaluative attitudes towards external objects. Based on the conception of contextual dependence of perceptual content, the role of intent in its formation has been determined. Intent is the driving force for evolution of the content of perceiving reality in individual's consciousness. Besides, intent facilitates both the creating of the new content of perceiving the future and changing of the content of reality perception. Individual's future behaviour is formed under the impact of these types of the content. Methods of psychosemantics and theory of planned behaviour are used for analysing perceptual contexts and predicting behaviour of an individual.

Keywords: perceptual context, perceptual content, intent, psychosemantics, behaviour, planned behaviour theory.

\section{Introduction}

One of the major problems of cognitive psychology and philosophy is the essence and principles of the formation of perceptual content, i.e. the content of information that is being conveyed in the process of perceptual experience.

Review of recent research works on the abovementioned issues demonstrates that the aspects of the formation of perceptual content and behaviour were considered by foreign psychologists: N. Medvedev,
N. Petrenko, F. Stanzhevskyi, A. Turchak, I. Ajzen, K. DeRose, J. Hawthorne, B. Muñoz, B. Phillips, $\mathrm{K}$. Weber et al. However, these issues remain underinvestigated in domestic psychological studies.

The paper aims to study and identify the factors affecting individual's interpretation of his/her own perceptual states as the reason for making decisions concerning the choice of certain behavioural reactions. Recognising these factors is of great importance for handling applied 
problems in management, public communications policy, commercial relations, etc.

The task of the study is to investigate the interaction principles of perceptual content and human behaviour.

Research methods: system analysis, critical overview of contemporary literature, synthesis of existing conceptual approaches to the issues of information perception.

\section{Discussion}

In recent decades, one of the main approaches to describing and investigating the content of human consciousness has been the one developed in psychosemantics. The object of psychosemantics is the content and functioning of individual and collective consciousness [2, p. 58]. Psychosemantic approach is based on the idea about the attributing of certain meanings to the observed things or phenomena by an individual. The sets of these meanings form individual fields of meanings in human consciousness. Communication between individuals in their daily living activities is carried out by means of delivering the above-mentioned meanings. In this case, estimation of communication efficiency may be performed by means of comparing the states of its participants' semantic spaces before and after communication acts [2, p. 330]. Changes of the states of the semantic spaces affect the formation of individuals' intents, which determines their behavioural reactions. Accordingly, psychosemantic methods make it possible to find out the principles of interaction between human consciousness and behaviour and predict individual's activities. Psychosemantics applies various numerical models and analysis methods that provide an opportunity to study the peculiarities of individual consciousness. It should be noted that unlike classical psychometrics qualimetric studies of experimental psychosemantics are more painstaking, as long as every person is a bearer of a unique semantic space, where every point reflects individual's attitude towards a certain individual object [2, p. 190].

At the same time, methods of psychosemantics cannot determine the way, in which individual fields of meanings reflecting perception of an object are formed. Perceptual content is often considered as the interpretation of qualitative characteristics of mental states, which is based on a certain modification of representationalism theory. In simplified form, its principal idea is that human consciousness reflects objective reality that is "external" in relation to a person. Correspondingly, within the framework of this theory, representation is the inner mental state reflecting the outside world, whereby this state causally precedes the subject's activity [3, p. 88]. In this regard, the traditional paradigm of understanding the activity of human consciousness involves its interpretation as the way of passive perception and processing of information about objective data, which is generated by the outside world [3, p. 88]. However, this paradigm has some problems, namely perceptual content's ambiguity [9, p. 5]. Under these circumstances, as noted by B. Phillips, researchers underestimate the degree of ambiguity of mental states' contents on the one hand, and the capability of these contents to fulfil explanatory function in individual's consciousness regardless of their ambiguity on the other hand $[9$, p. 6].

Based on a number of existing experiments, it can be demonstrated that even with regard to general vision it is impossible to define the object that sees the subject exactly as well as it is impossible to state that the content of the state of seeing corresponds to some definite external objects or their properties [9, p. 3-4; 7, p. 163]. The argumentation related to seeing can be expanded to any ways of the real world perception [6]. Therefore, it can be assumed that perceptual states may have a great number of different and at the same time equally possible interpretations $[9$, p. 4]. The most significant interpretation can be the one that is understood as "image of an object", and its significance is determined by observer's interests in the context of a certain situation, which is to be interpreted [9, p. 4].

Determinacy of perception or non-perception of an object (as well as perception of relation between an object and its part, and a set of characteristics required for perceiving an object) depends on the observer's interest in explaining certain aspects of a situation, i.e. on the context that the observer is involved in [9, p. 4]. Also, contextual dependence of perceiving information about object properties is obvious. For example, trueness of the statement "high" about a man will vary depending on the context of this man's image perception by information recipient ("high" compared to other people's height or "high" for a member of a basketball team) [9, p. 51].

According to this point of view, perceptual content (a set of meanings attributed by the recipient to the elements of his/her mental state arising in the process of receiving data about objects) depends on the situational context, which is interpreted by an individual in accordance with his/her own interests and attitudes. Contextual dependence of information perception and comprehension was considered in the works by K. DeRose, J. Hawthorne, and B. Phillips. In N. Petrenko's opinion, psychosemantics is based on the idea about pluralism of worldviews, which are formed under the impact of the observer's prejudice [2, p. 196]. It means that information recipient is not a passive receiver of some data, but an active subject of a communicative process. As noted by F. Stanzhevskyi, perception is an active process of an organism existing in a certain environment and ingrained in it [3, p. 94].

When describing the perceptual content in the process of communications, two components can be distinguished: the subjects' activities [2, p. 194; 1, p. 5] and their interests (motives) [9, p. 4; 2, p. 79].

Within the framework of this approach, it is necessary to specify some aspects. Firstly, it is reasonable to consider the concept "activities" in its broad sense, including all the aspects of human living: strictly professional activities (which are the basis for perceptual content) and mental processes (reflection, contemplation, etc.). As for the impact of individuals' interests on the formation of meaning, it should be noted that interest in 
its general sense is an objective factor in relation to a human, which has its contextually-dependent projection in his/her consciousness (the scope of meanings) and is associated with his/her "interests" (in this case, we are dealing with "negative infinity" of interpretations). That is why, we should speak about individual perception of one's own interests, i.e. involvement of communication recipients, which is reflected in their emotional and evaluative attitudes towards the objects. Thus, the context of human perception of objects in general terms can be defined as a result of mutual impact of the content and conditions of individual's living, and the so-called "involvement vector" related to it (a complex of emotional and evaluative attitudes towards objects).

Considering current perceptual context of the real world as the basis for the content of its perception, we can develop a relatively static model, which, obviously, cannot be the predictor of the character of an individual's future behaviour. In order to understand possible directions of changing individual's living activities, it is necessary to create a model that includes a complementary factor, namely individual's intents. According to A. Turchak's definition, intent is considered as a certain "conscious decision, which fulfils a function of stimulating and planning individual's behaviour and activities ... and is characterised by a certain goal and decision-making" [4, p. 309]. The goal is the imaginary desired change of the conditions and content of living. Accordingly, intent involves the created new context that determines a certain perception of the expected future reality depending on the desired changes and new aspects of involvement associated with the goal. It should be noted that from the standpoint of the above-mentioned conception of perceptual content's ambiguity (its relative independence on the real world), the principles of forming future perceptual content are almost the same as the principles of forming the content of existing reality perception. So, perception of the future depends on the new perceptual context that was formed as a result of individual's visions of anticipated future changes in the environment surrounding him/her and the understanding of his/her new interests associated with the intent. In this case, intent is the driving force for evolution of the content of reality perception in individual's consciousness. Besides, intent facilitates both creating the new content of perceiving the future and changing the content of perceiving the existing reality. For example, if a person is intending to move to another place, information concerning events taking place in his/her current place of living may disappear from his/her perceptual content or his/her attitude towards it will change significantly.

Based on the current perceptual content, intent involves the context of perceiving the future, which determines perceptual content of the future and affects the current perceptual content. Therefore, under the impact of both types of the content, future behaviour of an individual is formed. From the standpoint of psychosemantic approach, the process of changing perceptual context and content is reflected in certain changes of individual's space of meanings that are attributed to the objects of his/her own attention.

The interrelations between perceptual context and content, intent and behaviour can be represented schematically (Fig. 1).

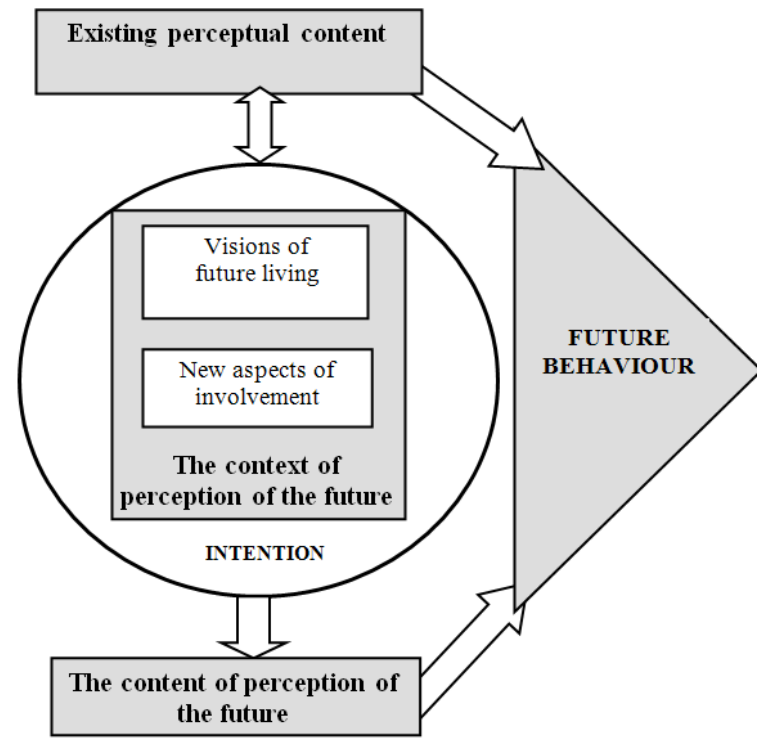

Fig.1. Interrelation between perceptual context and context, intent and behaviour

It is important to mention that behaviour is not the result of either "objective" conditions of human living or his/her "objective" interests, but, first of all, it depends on the sets of meanings in the individual space of human consciousness, which are continuously being formed and developed under the impact of current perceptual context and visions of the desired future. Accepting this point of view makes it possible to conclude that it is not enough to segment target audience in the process of developing communicative strategies and predicting human behaviour taking into account only demographic or socioeconomic criteria. These criteria appear to be insufficient, as long as information perception is characterised by the above-mentioned contextual dependence.

Traditional communication theories have certain concealed falseness, as they interpret a meaning as the one that can be transmitted from the source to a recipient $[1$, p. 2].

It is worth noting that this aspect of communication has remained understudied by domestic researchers. It seems that in many cases communication is based on the idea about possibility of general understanding of certain facts, events, phenomena, and results of their analysis by the authors of messages. However, in order to provide effective communication, the recipient should be able to understand perceptual context of the author of the message and be interested in its interpretation in general. The absence of proper understanding of individual's information perception makes it impossible to predict his/her future behaviour in any way. 
One of the main reasons for popularity of traditional understanding of a communicative process as a transmission of the sets of objective meanings is the implicit idea about relative similarity of the objective reality's contexts within the society as a whole or at least in major social groups. This idea was particularly developed in the second half of the XX century due to globalisation processes and increased role of the media, particularly television, which has led to certain unification of information perception contexts across the globe. Recently, the situation has somewhat changed. Under the conditions of postindustrial economics, rapid development of communication channels and information acquisition, with the help of the Internet, the process of society's fragmentation began to develop significantly. Accordingly, various groups of people may have significantly different contexts of information perception. It can be said that there is a gap in the common information space even in the developed countries where the population has almost unlimited access to the content of principal information sources.

As a result, under modern conditions of information society development, the importance of considering psychological factors when analysing information perception processes and predicting corresponding behaviour of individuals is increasing. Apart from methods of experimental psychosemantics, the theory of planned behaviour developed by Ajzen may be used as a theoretical basis for research [3]. According to it, individual intents preceding behaviour as well as behaviour itself are formed under the impact of attitudes towards it, "subjective standards" (perception of society's impact on behavioural decisions), "descriptive standards" (perception of other people), and perception of "behavioural control" (assessment of one's

\section{REFERENCES}

1. Medvedev, N. V. (2014). Priroda chelovecheskoy kommunikatsii [The nature of human communication]. Vestnik TGU - Bulletin of TSU, 12 (140), 1-5 [in Russian].

2. Petrenko, V. F. (2009). Mnogomernoe soznanie: psikhosemanticheskaya paradigma [Multidimensional consciousness: a psychosemantic paradigm]. Moscow: Novyi khronograf [in Russian].

3. Stanzhevskiy, F. A. (2015). K «pragmaticheskoy» i interaktivnoy paradigme issledovaniya intersubyektivnosti [About "pragmatic" and interactive paradigm of investigating intersubjectivity]. Epistemologiya $i$ filosofiya nauki - Epistemology and philosophy of science, 2 (44), 90-104 [in Russian].

4. Turchak, A. L. (2011). Formuvannia sotsialnoi potreby fizychnoho vdoskonalennia u studentiv vyschykh pedahohichnykh navchalnykh zakladiv [Formation of social need for physical improvement in students of higher educational institutions]. Naukovi zapysky KDPU. Seriia: Pedahohichni nauky - Scientific notes of KSPU. Series: Teaching Sciences, 97, 306-310 [in Ukraine].

5. Ajzen, I., \& Fishbein, M. (2005). The influence of attitudes on behavior. Handbook of attitudes. (pp. 173- own capabilities against the background of certain behaviour). One of the examples of the efficient use of the theory of planned behaviour for the analysis of psychological factors' impact on behavioural decisions of individuals is presented in the work of B. Muñoz and others [8]. This research demonstrated the existence of relation between these decisions and perceptual content (way of living and personal preferences and attitudes, the data of which were structured according to the theory of planned behaviour).

\section{Conclusions}

With the spreading of diverse forms of communication due to modern information technologies, we can observe the processes that can reflect a certain fragmentation of the common information space within traditional linguistic and cultural communities, which contributes to the society's fragmentation. This process leads to complication of communications and corresponding difficulties in predicting individual's behaviour. Under contemporary conditions, it is necessary to employ with this purpose psychological factors that affect individual's perceptual content. The approaches based on the conception of perceptual content's contextual dependence, methods of psychosemantics and the theory of planned behaviour are considered to be promising in this regard. Perceptual context is considered as a result of mutual influence of the content and conditions of individual's living and corresponding involvement vector. Changes of the perceptual content are determined by individual's changeable intents, which predict further actions. According to the conception of contextual dependence, analysis of the content of perception of the future can be performed with the use of the same methods (including methods of planned behaviour theory) as the analysis of current perceptual content.

221). D. Albarracin, B. T. Johnson, M. P. Zanna (Eds.). New Jersey: Lawrence Erlbaum Associates [in English].

6. DeRose, K. (2009). The Case for contextualism: knowledge, skepticism, and context. Oxford: Oxford University Press [in English].

7. Hawthorne, J. (2004). Knowledge and lotteries. Oxford: Oxford University Press [in English].

8. Muñoz, B., Monzon, A., \& Lois, D. (2013). Cycling habits and other psychological variables affecting commuting by bicycle in Madrid, Spain. Transportation research record journal of the transportation research board, 2382(1), 1-9 [in English].

9. Phillips, Ben S. (2016). Seeing and perceptual content. CUNY Academic Works. Retrieved from: http://academicworks.cuny.edu/gc_etds/1405 [in English].

10. Weber, K. (2013). Access to information and fragmentation of knowledge and society. DOI: $10.2139 /$ ssrn.2234477. Retrieved from: https://www.researchgate.net/publication/256052865_Acc ess_to_Information_and_Fragmentation_of_Knowledge_ and_Society [in English]. 


\section{ЛІТЕРАТУРА}

1. Медведев Н. В. Природа человеческой коммуникации / Н. В. Медведев // Вестник ТГУ. - 2014. - 12 (140). - C. 1-5.

2. Петренко В. Ф. Многомерное сознание : психосемантическая парадигма / В. Ф. Петренко. - М. : Новый хронограф, 2009. - 440 с.

3. Станжевский Ф. А. К «прагматической» и интерактивной парадигме исследования интерсубъективности / Ф. А. Станжевский // Эпистемология и философия науки. - 2015. - № 2 (44). - С. 90-104. Москва : Институт философии РАН.

4. Турчак А. Л. Формування соціальної потреби фізичного вдосконалення у студентів вищих педагогічних навчальних закладів / А. Л. Турчак // Наукові записки КДПУ. Серія : Педагогічні науки / ред. В. В. Радул [та ін.]. - Кіровоград : КДПУ, 2011. - Вип. 97. - С. 306-310.

5. Ajzen I. The influence of attitudes on behavior / I. Ajzen, M. Fishbein // Handbook of attitudes ; edited by D. Albarracin, B. T. Johnson, M. P. Zanna. - New Jersey : Lawrence Erlbaum Associates, 2005. - P. 173-221.
6. DeRose K. The case for contextualism: Knowledge, skepticism, and context / K. DeRose. - Oxford : Oxford University Press, 2009.

7. Hawthorne J. Knowledge and lotteries / J. Hawthorne. - Oxford : Oxford University Press, 2004.

8. Muñoz B. Cycling habits and other psychological variables affecting commuting by bicycle in Madrid, Spain / B. Muñoz, A. Monzon, D. Lois // Transportation research record journal of the transportation research board. -2013 . $-1-9$.

9. Phillips Ben S. Seeing and perceptual content [Електронний pecypc] / Ben S. Phillips // CUNY Academic Works. - 2016. - Режим доступу : http://academicworks.cuny.edu/gc_etds/1405.

10. Weber $\mathrm{K}$. Access to information and fragmentation of knowledge and society [Електронний pecypc] / K. Weber. - 2013. - DOI :10.2139/ssrn.2234477. - Режим доступу : https://www.researchgate.net/publication/256052865_Acc ess_to_Information_and_Fragmentation_of_Knowledge_ and_Society.

Марина Свгенівна Пулясвська, кандидат психологічних наук, стариий викладач кафедри соиіально-гуманітарних дисциплін, Міжрегіональна Академія управління персоналом, вул. Фрометівська, 2, м. Київ, Україна

\section{РОЛЬ КОНТЕКСТУ ТА НАМІРУ В ФОРМУВАННІ КОНТЕНТУ СПРИЙНЯТТЯ ТА ПОВЕДІНКИ}

Статтю присвячено дослідженню та визначенню чинників, які впливають на інтерпретацію індивідом власних станів сприйняття як підстави для прийняття рішень про вибір тих чи інших поведінкових реакцій. Виявлення таких чинників має суттєве значення для вирішення багатьох прикладних задач в сфері управління, інформаційної політики, комерційних відносин тощо. В роботі досліджено певні закономірності взаємодії контенту і контексту сприйняття та поведінки людини. 3 поширенням різноманітних форм спілкування за допомогою сучасних інформаційних технологій мають місце процеси, що можуть вказувати на певний ступінь фрагментації єдиного інформаційного поля всередині традиційних мовно-культурних спільнот, що сприяє фрагментації суспільства. Цей процес призводить до ускладнення комунікацій та відповідного ускладнення прогнозування поведінки індивідів. В сучасних умовах необхідним є поширення використання 3 цією метою психологічних чинників, які впливають на контент сприйняття людини. Значні перспективи в цьому напрямі відкривають підходи, основані на концепції контекстуальної залежності контенту сприйняття, методах психосемантики та теорії планованої поведінки. Під контекстом сприйняття розуміється результат взаємовпливу змісту і умов життєдіяльності індивіда та пов’язаного з ними «вектора зацікавленості». Зміни контенту сприйняття визначаються мінливими намірами індивіда, які створюють уявлення про майбутнє та служать орієнтирами для подальших дій. Згідно з концепцією контекстуальної залежності, аналіз контенту сприйняття майбутнього може бути виконаним із використанням тих же методів (зокрема методів теорії планованої поведінки), що ї аналіз поточного контенту сприйняття.

Ключові слова: контекст сприйняття, контент сприйняття, намір, психосемантика, поведінка, теорія планованої поведінки.

Submitted on 20, February, 2017 